\title{
ねばい材料を得るための方法
}

\section{須 藤}

\section{強さともろさ}

金属は針金にも䇴にも加工寸ることができる。

あめや粘土も容易に変形させることができる。し かし後者が非晶質であるのに対して，金属はこれ を構成している原子が整然と配列した結晶体であ るから，両者の変形のメカニズムは全く異なって いる、岩塩などの非金属鉱物も結晶体であるが， これらは延性を示さない。すなわち，金属では原 子配列の密な特定の面で非常にすべりやすい性質 があって，これが金属の代表的な特徵である延性 の原因となっている。

冷間加工，合金元素の添加，焼入れや時效など の熱処理によって金属は強くなる．強さとは変形 に対する抵抗力のことである．金属がいろいろの 手段によって強くなるのは, 前述の特定の結晶面 がゆがんだり，大きさの異なる原子や，硬い析出 物がばらまかれたりして，原子面のすべりが困難 になったからである。このよらにすべての強化手 段は原子面がすべりやすいという金属の本性に逆 ららものであるから，強くするほどにもろくなる ことは一般的には避けられないことである。しか しながら,(強さ) $\times($ 延性) =(ねばさ)は,強化の手 段によって大いに異なる。技術文明発展の舞台で 金属材料技術者の活踓がもっとも期待される場面 の 1 つは，よりねばい材料を得るための手段を見

* 東北大学教授; 工学部金属材料工学科

Toward Improved Toughness ; Hajime Suto (Faculty of Engineering, Tohoku University, Sendai) 1976 年 11 月 8 日受理
出していくところである。その際の 1 つの粗筋と して愚見を述べさせていただく。

\section{弱点をいやし，ストレスの 集中を避ける}

体を鍛える際に弱点にストレスが集中しないよ らに注意しなければならない。単純明快なこの原 則を材料にあてはめてみよう。

\section{鋼の熱処理の意味}

焼ならした構造用鋼は(硬くてもろいパーライ ト)と(弱くて延性のあるフェライト)の粗い混合

(a)

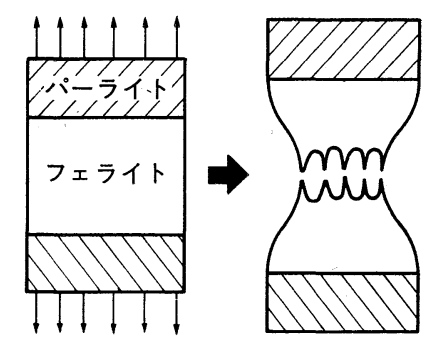

(b)

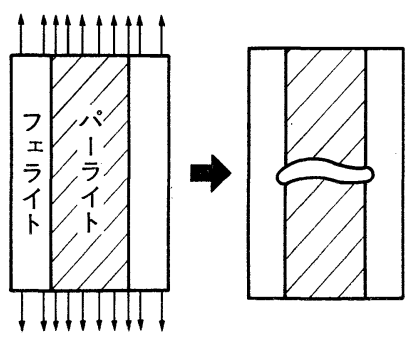

図 1 もろいパーライト・フェライト複合材 の性質. 
組織の鋼である。図 1 (a) は両相が直列に並んで 応力を受けた状態を示すが，このときの強度は フェライトのそれにほぼ等しい. (b) は両相が並列 の場合で, その伸びはもろいパーライトによって 決ってしまう．実際の鋼は(a) と (b)の両方を含む が，外力を受けるとそれぞれの弱点にストレスが 集中して，ねばさが十分上らない。一般に組織の 粗い混合組織合金のねばさは構成相のねばさの算 術平均よりも低下寸る。このことは近年脚光をあ びている複合材料を考劣る場合に重要なことであ る。これに対して焼入れ焼もどし材はフェライト 基地に粒状の $\mathrm{Fe}_{3} \mathrm{C}$ が均一にばらまかれているか ら，材料全体が一様に力を受け，一様に变形して ねばい挙動を示す。

\section{結晶粒を細かくしよう}

原子密度の高い結晶面に大きな引張り力がかか ると，この面でへき開破壞が起ることがある。多 結晶体に外力 $\sigma$ がかかったとき，粒径 $d$ のある結 晶粒内にへき開割れが起ったとする。この割れ の先端の曲率半径を $\rho$ とすると, 割れ先端には $\sigma \sqrt{d / \rho}$ 程度のストレスの集中が起る。すなわち, 結晶粒径が大きいほど割れは拡大しやすい。すべ り変形の場合も同様で，方位がそれぞれ異なる結 晶粒を単位にすべりが起り, 結晶粒界には $\sqrt{d} に$ 比例するストレスの集中が起る。これは強さと延

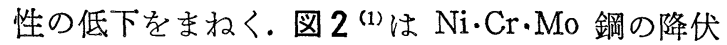

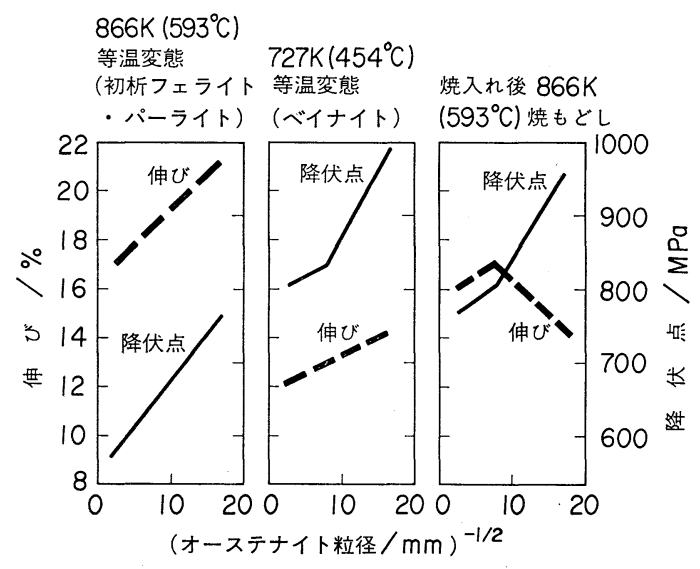

図 2 Ni.Cr.Mo 鋼のオーステナイト粒径と 降伏点，伸びの関係．(Grange)
点,伸びと組織の関係を示す.パーライトやベイナ イトを含む鋼では旧オーステナイト結晶粒径を微 細化することによって降伏点も伸びも上昇する。

焼入れ尭もどし材はもともと均一微細な組織でね ばい材料であるから，細粒化によって伸びはあま り変わらないけれども，降伏点は上昇し，強勒と なる。

しかし，このよらな焼もどし鋼を $773 \mathrm{~K}\left(500^{\circ} \mathrm{C}\right)$ 付近で再度焼もどしたときに起る焼もどし脆性 （Pなどの不純物が粒界に集まり，粒界にストレ スがかかると粒界で割れる) に対しては図 $3^{(2)}$ に 示すよらに細粒化は效果を示す，高張力鋼などで は, 衝撃遷移温度 $\left({ }_{V} T_{S}\right)$ は粒径 $d(\mathrm{~mm})$ とともに $-20 d^{-1 / 2}(\mathrm{~K})$ の割合で低下する。

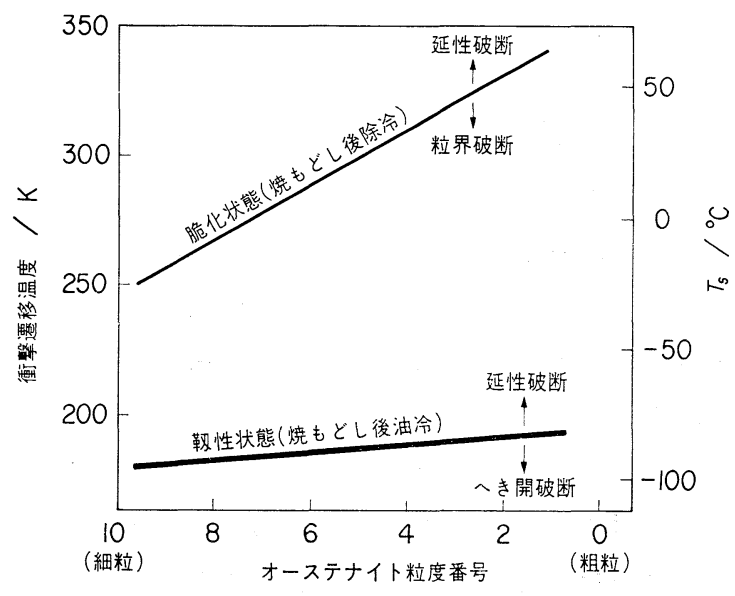

図 $3 \mathrm{Ni} \cdot \mathrm{Cr}$ 鋼 $(0.3 \mathrm{C}, 3 \mathrm{Ni}, 1 \mathrm{Cr}, 0.03 \mathrm{P})$ の 衝擊遷移温度と結晶粒径の関係。(船越, 他)

\section{少量の第 2 相を微細に分散させること}

剛性率 $G$, すべり方向の原子間距離 $b$ の基地に 硬い粒子を間隔入でばらまくと，その降伏点は大 体 $G b / \lambda$ だけ上昇する，一方図 $4^{(3)}$ のごとく，材 料の延性は第 2 相の体積率にほぼ逆比例して減少 する。この傾向は基地とのなじみの悪い非金属介 在物で著しい。したがって強勒化のためにはなる べく基地とよくなじむ少量の第 2 相をできるだけ 微細にばらまくことと非金属介在物を極力減らす ことである。

固溶強化だけで材料を強くする方法はどうであ ろら。この場合すべり面に強固な障害物がないか 


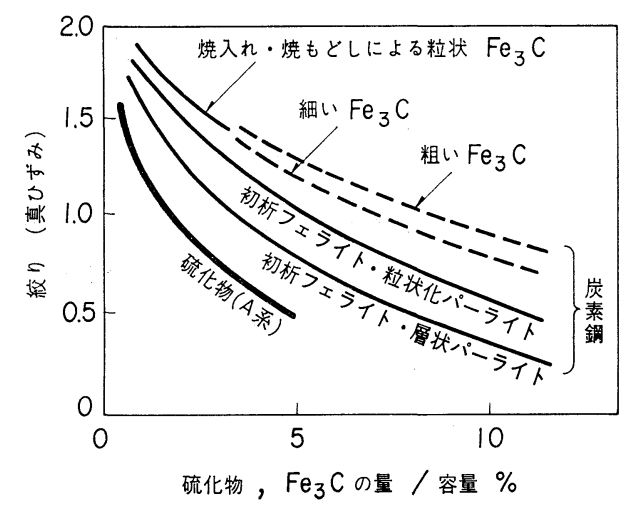

図 4 鉄の延性に及ぼす第 2 相の影響.

(Pickering)

ら, 降伏点以上の応力がかかるとすべりは一挙に 結晶粒界まで進んでここに大きなストレスが集中 する。したがって固溶強化だけであまり硬くした 合金はもろくなる.

図 $5^{(4)}$ は Al-1.5\% Si 合金の例であるが，453 K $\left(180^{\circ} \mathrm{C}\right)$ と $473 \mathrm{~K}\left(220^{\circ} \mathrm{C}\right)$ で時效したときの性質を 較べてみると強度が等しく, 延性は前者の方が優 れている。このことは, 前者は時效析出がまだ不 十分のため, Si の一部は固溶して, 残部の $\mathrm{Si}$ が微 細に析出している.このように, 固溶強化と析出強 化を複合して使用することは大变意味がある(4).

多数の核を微細に発生させるには基地と析出物

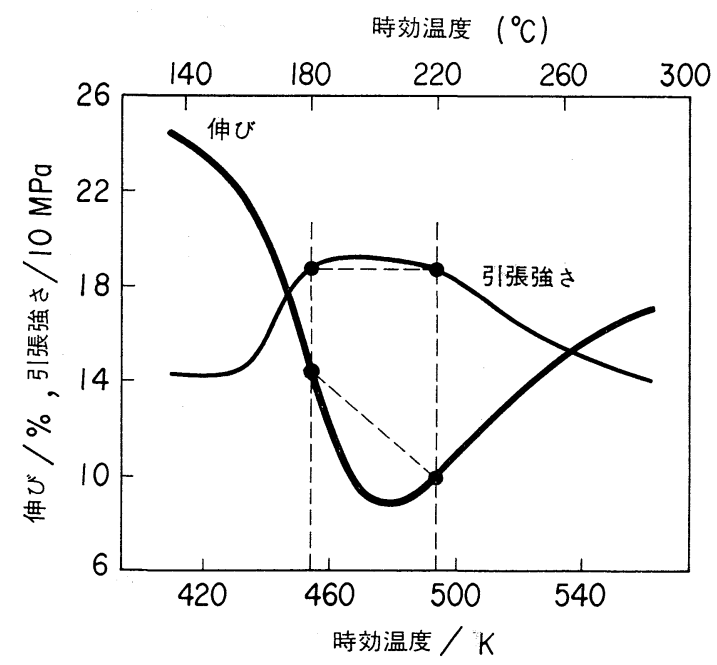

図 $5 \mathrm{Al}-1.5 \% \mathrm{Si}$ 合金の時効による引張り強さ, 伸びの变化 : $3.6 \mathrm{ks}$ (1 hr) 時効. (須藤)
の原子面が連続している(整合)ことが好都合であ る。整合析出物にはストレスが集中する界面がな いから延性を損わないように思われる。しかしこ のような合金では，固溶体合金の場合と同様に過 大応力がかかるとすべりは一举に粒界まで進み， 材料を破壊に導く。たとえば Fe-30\% Cr 合金は $748 \mathrm{~K}\left(475^{\circ} \mathrm{C}\right)$ で時效すると $\mathrm{Fe}$ 側固溶体と $\mathrm{Cr}$ 側固 溶体に分解するが，両相は全く整合である。そし て脆化する $\left(475^{\circ} \mathrm{C} \text { 脆性 }\right)^{(4)}$.

図 $6^{(5)}$ は $12 \% \mathrm{Ni}-6 \% \mathrm{Mn}$ 鋼マルテンサイトの時 効に伴う性質の変化を示す。この場合 NiMn 整合 相の析出により硬化されるが，粒界で脆性破壊が 起る。粒界に Mn, Niがとくに富化されることが 粒界破壞に一役買っている(6)(7) か子知れないが, 粒内の NiMnがすべり切られないように $20 \mathrm{~nm}$ $(200 \mathrm{~A})$ 以上飞大きくして，つまり過時効によりす べりが粒界まで一挙に走らないようにして靶性を 得ることができる。

粒界は原子配列が乱札ているので，エネルギー が高い。このために析出核が粒内よりも粒界に発 生しや寸い。 かくして粗大な粒界析出物が形成さ れると，粒界であるためのストレスの集中と異相 が存在するためのストレスの集中が重なって材料 はもろくなる。粒界近傍の溶質原子が集合して粗
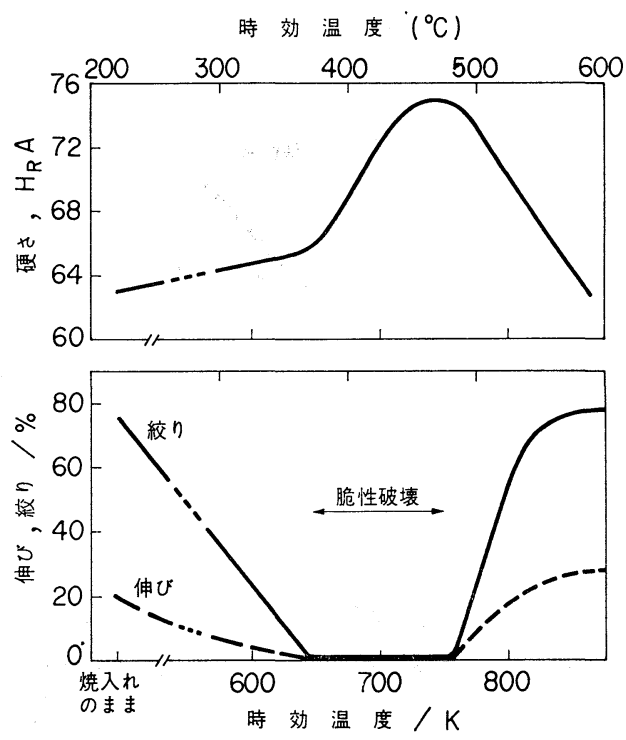

図 $6 \quad 12 \% \mathrm{Ni}-6 \% \mathrm{Mn}$ 鋼マルテンサイトの時効 に伴う機械的性質の変化. (田中, 他) 
大な粒界析出物を形成するのに伴って, 無析出帯 (PFZ) が粒界のまわりにできることが多い。この ような軟質相が粒界のストレスを緩和して勒性の 向上に役立つであろらか.工具鋼や極低温の衝撃 試験で鋼がへき開破壞をするような非常にもろい 破壊の場合は, 郔性に富む微細な残留オーステナ イトによってき裂の先端が鈍化して脆性き裂の伝 ぱがここで止められる場合はある。しかし延性材 料に扮いてはき裂の先端はもともと鋭くはないの でこのよらな效果は期待できない。

たとえば過時效状態のマルェージング鋼は粒界 にオーステナイトが存在するけれども，これは勒 性に役立たない(8)。これに関してTiCなどの粒界 析出が起るためとする考它もある。ともかく粒界 析出物と PFZ が共存する場合は粒界に限定された 小さな伸びを含む粒界破壊が起る(9)。図 $7^{(10)}$ はこ のような粒界延性破壞を起す $\mathrm{A} 1-6 \% \mathrm{Zn}-1.5 \% \mathrm{Mg}$ 合金が，時效前の冷間加工により。析出物の核発 生が粒内でも容易となり，粒界析出と PFZ の発 達が抑制され，粒界破壞しなくなって勒性が向上 することを示す。

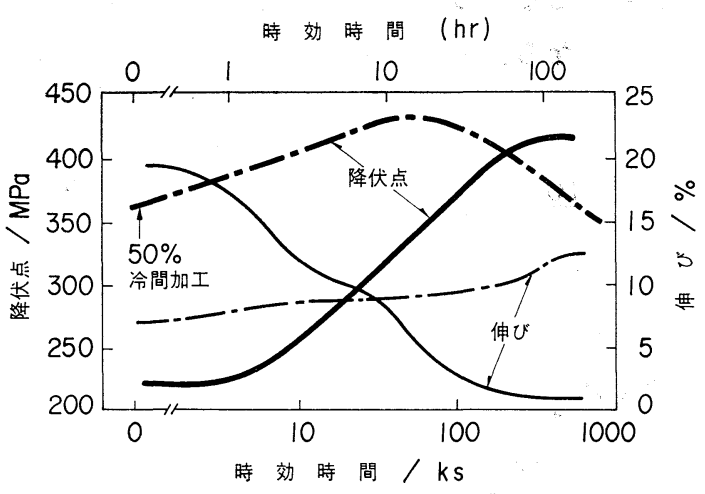

図 $7 \mathrm{Al}-6 \% \mathrm{Zn}-1.5 \% \mathrm{Mg}$ 合金の $393 \mathrm{~K}\left(120^{\circ} \mathrm{C}\right)$ 時効による降伏点, 伸びの変化.

実線：普通時効，鎖線：ひずみ時効

以上要するに, 少量の強い粒子を粒内に均一微 細にばらまき，粒界析出を防ぎ，結晶粒径を小さ くしてストレスの集中を避けながら，固溶強化や 整合相を補助的に用いることにより，強靱材料が 得られる場合が多い。

\section{原則を理解し，これを 超越すること}

たとえば混合組織合金の延性は低いといら概念 をらのみにしてはいけない，2相合金を加熱した ときの粒成長を考える。各結晶粒は組成の大きく 異なる別の相で包囲されているので，単相合金の 場合よりも粒界移動が困難で, 粒成長が起りに くい.このために多くの Ti 合金 $(\alpha / \beta), 4 \cdot 6$ 黄銅 $(\alpha / \beta), 2$ 相ステンレス鋼 $(\alpha / \gamma)$ などの混合組織合 金は焼なまし状態でも結晶粒が微細であり，粒界 にストレスが集中する程度が低い。これらの実用 合金では両相がともに延性をもち，強さに大きな 差がないといら点も，粒界にストレスを集中させ ないための大切な因子となっている。では軟かい フェライトと硬い $\mathrm{Fe}_{3} \mathrm{C}$ の混合組織の場合はどう であろらか.共析鋼を $823 \mathrm{~K}\left(550^{\circ} \mathrm{C}\right)$ 付近で恒温変 態させ (パテンティング), 強く冷間引抜きをして $\mathrm{Fe}_{3} \mathrm{C}$ とェライトが繊維状に配列した超微細組織 とする。フェライトは冷間加工と $\mathrm{Fe}_{3} \mathrm{C} か ら \mathrm{C}$ 原 子の供給を受けて, その強度は低炭素マルテンサ イトほどに達し(11)， $\mathrm{Fe}_{3} \mathrm{C}$ との強度差が縮まる。 このよらにして工業用材料として, 最も強勒なピ アノ線ができあがるのである。ストレスの集中は 疲れ破壊の場合にとくに問題になる。マルテンサ イトとオーステナイトの混合組織合金の疲れ強さ は,オーステナイトのみの場合と同程度に低いけ れども, 冷間加工によりオーステナイトを強化し てやれば耐久比が向上 ${ }^{(12)}$ することも同様な考え で理解できる。

機械構造用鋼をまず通常焼入れを行ない，次に $\mathrm{A}_{\mathrm{c} 1}$ と $\mathrm{A}_{\mathrm{c} 3}$ の中間の温度から焼入れる。この熱処 理は一様な組織をつくるという原則から外れた方 法であるが，これによってオーステナイト粒径が 微細になり，䍒もどし脆化が起りにくくなる。こ の方法は $9 \% \mathrm{Ni}$ 低温用鋼の代用鋼である $6 \% \mathrm{Ni}$ $\mathrm{Cr} \cdot \mathrm{Mo}$ 鋼飞適用して成功を納めている(13).

あらかじめ深く鋭い切欠きを付した試験片を破 断させ，その破断荷重と試験片形状から脆性さ裂 の「伝ぱ」に対する抵抗のパラメーター $K_{\mathrm{IC}}$ を求 めることがある. 図 $8^{(14)}$ の $\mathrm{Ni} \cdot \mathrm{Cr} \cdot \mathrm{Mo}$ 鋼の結果で 


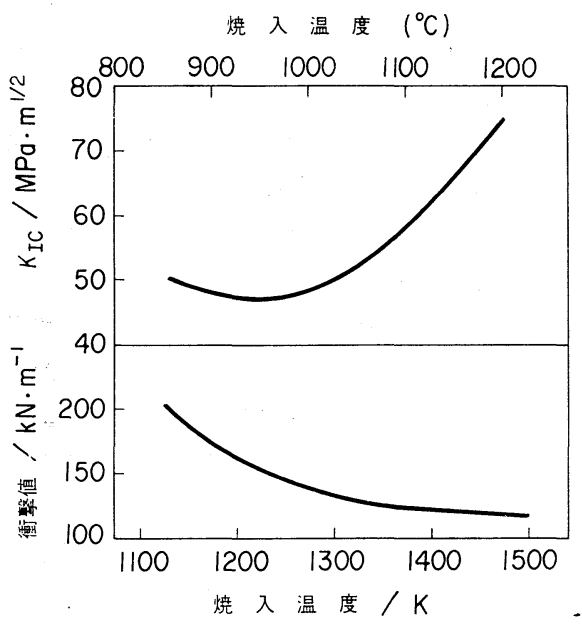

図 $8 \quad 0.4 \mathrm{C}-1.8 \mathrm{Ni}-0.6 \mathrm{Cr}-0.2 \mathrm{Mo}$ 鋼 $\left(473 \mathrm{~K}\left(200^{\circ} \mathrm{C}\right)\right.$ 焼もどし) の靱性 に及ぼす焼入れ温度の影響.

(Zackey，他)

は高温から焼入れて結晶粒径を大きくしたほらが $K_{\mathrm{IC}}$ が大きい。これは極めて鋭い切欠きの先端で のそ性変形が粗粒鋼ほど起りやすいことが関与し ている。しかし，粒界でのストレスの集中が脆性 き裂の「発生」に関与し，これが結果に反映する シャルピー試験では常識通りに粗粒のほうがもろ くなる。このように靱性の評価方法によって組織 の效果が異なってくることを留意すべきである。

\section{ねばり強く進歩しよう}

勒性という大問題をストレスの集中の一因子で 割り切って述べたが，納得できない事例がつぎつ ぎにでてくるであろう。その都度それらをまな板 にのせて考觉を深め, 細部の研究におま゙れず, 原 理・原則に縛られることなく自由な発想を実行に 移すところに進歩が期待できよう。

\section{文献}

(1) R.A.Grange: Trans. ASM, 59(1966), 26.

（2）船越督己, 榎並禎一：材料研究委員会報告, 鋼の焼 もどし脆性に関する研究，日本鉄鋼協会材料研究委 員会，(1976)，3月，9.

(3) F.B.Pickering : 鋼の強靱性, Climax Mo Dev. Co. (Japan), (1971), 9.

（4）須藤 一, 大貫 仁：金属学会誌, 39(1975), 792 .

(5) 田中 実, 山本 襄：文献 (3), 196.

(6) D. R. Squires and E. A.Wilson : Met. Trans., 3(1972), 575 .

(7) H.C.Feng, E.A.Wilson and C.J.McMahon : Proc. 3 rd Int. Conf. of Strength of Met. \& Alloys , (1973) , 129.

(8) C.A.Pampillo and D. W. Paxton : Met.Trans., 3 (1972), 2895.

(8) W. C. Johnson and D. F. Stein : Met. Trans., $5(1974), 549$.

（10）宇野照生，馬場義雄：金属学会講演概要，(1976. 10月), 60 .

(11) 須藤 一, 工藤利博 : 金属学会誌, 36 (1972), 693 .

(12) 須藤 一, 加賀 寿 : 金属学会誌, 37(1973), 1185 .

(13) 須藤 一：金属学会会報, 14(1975), 681 .

(14) V.F.Zackey, E.R.Parker and W.F.Wood: 文献 (7), 176

\section{〈新刊案内>}

\section{Boron Reinforced Aluminum Systems (Materials Technology Series, vol.6)}

\section{Carlos J.Hilado 編}

繊維強化型金属系複合材料が注目されてから大分 たつが，実用化へ大きく踏みだした例を余り聞かない が，中でも実用化へもっとも近い位置にあると見られ るのが, ボロン繊維強化型アルミニウム系で, この系 特有の高い比強度, 比弾性率から主に航空宇宙関係へ の応用が試みられている。本書はこの系の材料に関 する論文を，1971〜73 年の Journal of Composite Materials から集めたものであるが，論文執筆者の大 部分はアメリカの航空宇宙および軍関係の研究者であ って,アルミニウム系複合材料にとって最近何が問題 になっていたかを本書から伺い知ることができる。こ の方面の具体的情報に疎い我国の研究者にとって有効 な情報源の一つであろら。

さて内容であるが，複合材料内の応力分布について の, 有限要素法と Prandtl-Reuss 関係式を用いた弾 塑性解析拉よび, Boundary Point Least Squara (BPLS) 法による解析, 強度, 特に破壊強度の緎維方
向依存性についての試験結果，材料の振動特性の有限 要素法解析と実験結果, 圧縮荷重下の繊維の挫屈挙 動，設計思想からの材料の信頼性評価などが含まれて いる。

情報量が多すぎるためにかえって特定材料に関する 情報が分散しがちな現在, 本書のような集録は利用者 にとって便利なものである。しかしこの系の材料に関 する研究は日進月歩して扣り，その歩みから見れば本 書の内容は最新とはいい難い。たとえば，構造用複合 材料の応用に当って遭遇している主要問題の一つは衝 撃抵抗であって,特に本系のような航空宇宙用(ジェッ ト・エンジンのフィンおよびュムプレッサー・ブレー ド) 材料にとって問題なのはFOD (foreign object damage)であること[J.Composite Materials, 10 (1976)，231]などは複合材料の研究者にとって見逃せ ないことであろう。

\footnotetext{
[B 5 判 124 頁 1974 年 5.980 円 Technomic Pub.Co.]
} 